\title{
ARTificial BeACH NOURISHMENT on BeLgian EAST COAST
}

\author{
By Pierre Kerckaert, ${ }^{1}$ Paul P. L. Roovers, ${ }^{2}$ Ahrend Noordam, ${ }^{3}$ \\ and Paul De Candt ${ }^{4}$
} \begin{abstract}
AвstRact: For several decades, the Belgian East Coast has posed problems of
a sedimentological nature. Off the coast, a gully (called "Appelzak") has developed to a depth of $8 \mathrm{~m}$ below low-water and has shifted dangerously near the existing seadike, causing severe beach erosion. In 1976 the Belgian Government decided to sizeably enlarge the outer harbor of Zeebrugge seaward to a distance of $3.5 \mathrm{~km}$ from the coast, and to proceed with a significant beach restoration of about 8.5 million $\mathrm{m}^{3}$ of sand. An extensive observation program is carried out to study beach changes and to indicate unexpected developments, so that counter-measures can be taken in good time. Results of observations over the period June 1979 until February 1981 are examined using survey data from bathymetric soundings, aerial photogrammetry and terrestrial beach measurements.
\end{abstract}

\section{INTRODUCTION}

For several decades, the Belgian East Coast, situated next to the se estuary of the Western Scheldt, was subjected to significant beach ero sion. One of the resultant features was a gully about $8 \mathrm{~m}$ below low water level which developed very near the coast and caused serious beac] erosion via offshore transport (Fig. 1). Moreover, the building of the har bor at Zeebrugge (from 1897 to 1906) intersected the easterly flux of long shore drift so that less sediment came in along the coast than was nec essary for natural beach replenishment.

By 1974 the gully had approached to within $500 \mathrm{~m}$ of the seawall. A high water the beach nearly disappeared and at low tide a strip of onl 50-100 $\mathrm{m}$ was available. Moreover, the state of the beach-profile hai allowed storm-waves to approach the seawall, causing, on several or casions, damage to the seawall. It was thus imperative to draft measure for coastal protection.

In 1976 the Belgian authorities decided to extend the port of Zee brugge. This contract also included the study and execution of coastc protection works to prevent future erosion on the east coast. The con struction of the new outer port, which began in June 1979 and is du for completion in late 1986, will alter the hydraulic regime to a grea degree, and thus the beach morphology.

In 1977, prior to the port extension works, it was nevertheless decide to take direct action by spreading a total of 8.5 million $\mathrm{m}^{3}$ of dredge

${ }^{1}$ Chf. Engr.-Dir., Ministry of Public Works, Administration of Waterways, Coastic Service, Ostend, Belgium.

${ }^{2}$ Chf. Engr.-Dir., Ministry of Public Works, Hydraulics Research Lab., Borget hout, Belgium.

${ }^{3}$ Proj. Mgr., T.V. Zeebouw-Zeezand, Knokke-Heist, Belgium.

${ }^{4}$ Proj. Engr., N.V. Haecon, Ghent, Belgium.

Note.-Discussion open until February 1, 1987. To extend the closing date on month, a written request must be filed with the ASCE Manager of Journals. Th manuscript for this paper was submitted for review and possible publication o August 9, 1983. This paper is part of the Journal of Waterway, Port, Coastal an Ocean Engineering, Vol. 112, No. 5, September, 1986. CASCE, ISSN 0733-950X 86/0005-0560/\$01.00. Paper No. 20884. 


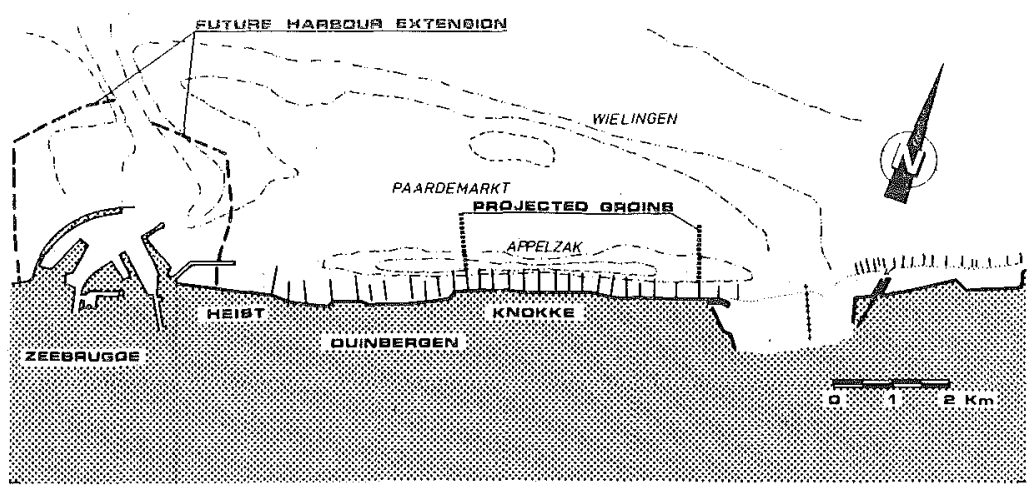

FIG. 1.-Belgian East Coast-Situation

sand over an $8 \mathrm{~km}$ long coastal strip between Zeebrugge and the Dutch border. As a result, most places once again enjoyed a $100 \mathrm{~m}$ wide beach at high tide.

To follow up this important beach nourishment, a comprehensive survey-program was set up to observe the further evolution of the beaches, and in this way, inform the authorities of any unexpected shifts of beach material.

\section{Preliminary Studies before Execution of Port Extension Works}

The hydraulic mechanism that induces sediment transport and the influence that the port extension would have on the coastal regime were both analyzed in a preliminary study, prior to beach nourishment (1).

Three types of erosion were identified for study-evaluation: (1) Wind effects on the newly-placed beach material-the possibility of eolean transport; (2) the hydrodynamics of littoral drift, and the effect of a different wave climate as a result of the new outer-port; and (3) the morphological effects under new tidal currents resultant from the seaward extension of the outer-port - the possibilities of tidal and offshore transport.

Eolean transport calculations (using the Bagnold formulae) and varying moisture contents of the beach led to an estimated sand loss of about $80,000 \mathrm{~m}^{3} / \mathrm{yr}$.

Shoreline changes were calculated with the theory of Pelnard-Considère. A mean littoral drift of $430,000 \mathrm{~m}^{3} / \mathrm{yr}$ directed north-eastwards was determined.

Tidal transport calculations were carried out, using a calibrated Bijker formulae which considers both the effects of waves and currents. Within the evaluation, different variants for coastal protection were considered.

From these calculations, a total beach erosion of $800,000 \mathrm{~m}^{3} / \mathrm{yr}^{\mathrm{sub}}$ sequent to beach nourishment could be forecast. The survey program mentioned earlier, must help to control the future situation and so confirm the reliability of these figures. 


\section{Execution of Beach Nourishment}

To carry-out beach nourishment, some 8.5 million $\mathrm{m}^{3}$ of sand was required. This was dredged offshore at about $20 \mathrm{~km}$ from the harbour at Zeebrugge. This sand was brought inshore by large self-propelled hopper-dredgers (with capacities between 5,000 and 7,000 $\mathrm{m}^{3}$ ) and dumped in a pre-dredged supply-pit. From here a cutter-dredger and a series of five booster-stations pumped the sand onshore. The maximum distance for the supply pipeline was $11 \mathrm{~km}$, for which a total installed power capacity of around $8,100 \mathrm{~kW}$ was needed.

The beach restoration was carried-out in two phases. In the first phase 2.6 million $\mathrm{m}^{3}$ of sand was pumped over a $5 \mathrm{~km}$ length of beach at a rate of $520 \mathrm{~m}^{3}$ of sand per running meter on the most eroded beaches. Thereafter, during the second phase, 5.8 million $\mathrm{m}^{3}$ was evenly distributed over some $8 \mathrm{~km}$ of coast, at a rate of about $725 \mathrm{~m}^{3} / \mathrm{m}$.

In-situ measurements have since shown that about $80 \%$ of the supplied sand established itself in the nearshore beach profile, with a loss of $15 \%$ due to differences measured in hopper capacity and beach volume. The remaining $5 \%$ can be attributed to the washing out of fine material by wave action.

\section{Follow-Up Program}

\section{Field Surveys}

Fig. 2 gives a general view of the follow-up program. Changes in coastal morphology are verified using echo soundings as well as data from pho-

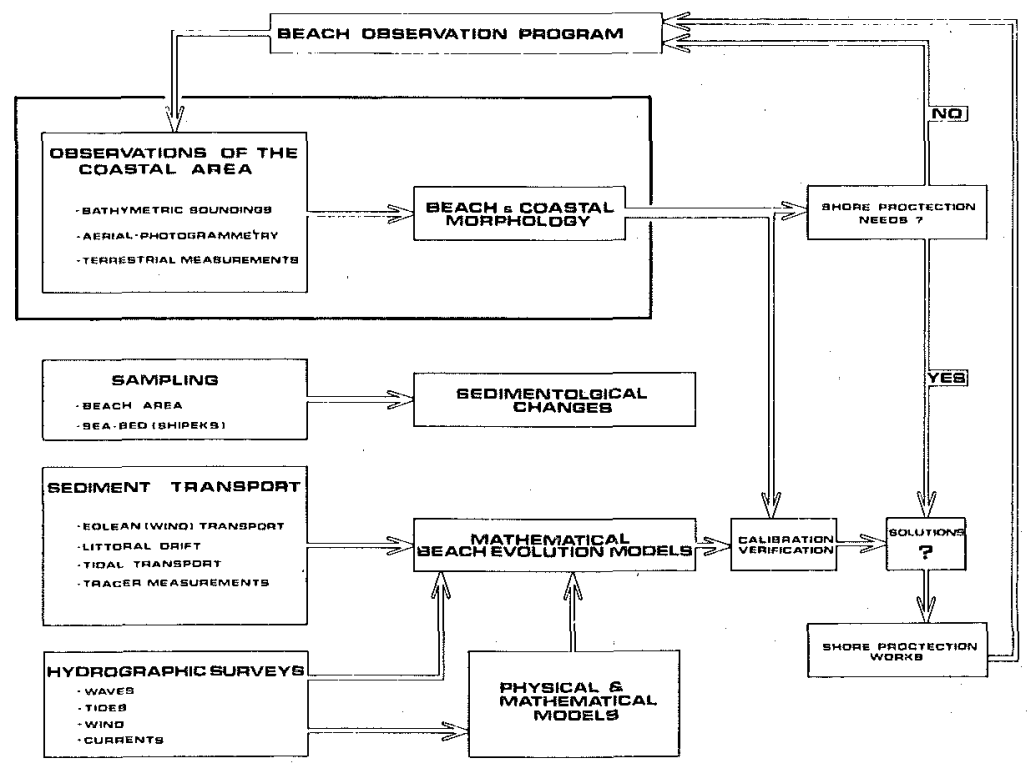

FIG. 2.-Follow-Up Program 
togrammetric and terrestrial surveys. Sedimentological sampling is carried-out around Zeebrugge; this includes both "dry-sampling" on the beach as well as "wet-sampling" (shipek-type) on the seabed. Sediment transport measurements are used for calibration of sediment transport formulae. Different types of transport are verified. The hydrographic surveys permit wind, wave, tide and current data to be used for calibration of physical and mathematical tidal models.

Both the results from transport measurements and tidal models are stored in mathematical beach evolution models, and the results of the beach and coastal morphology can then be compared to the calculations.

\section{DATA PROCESSINC}

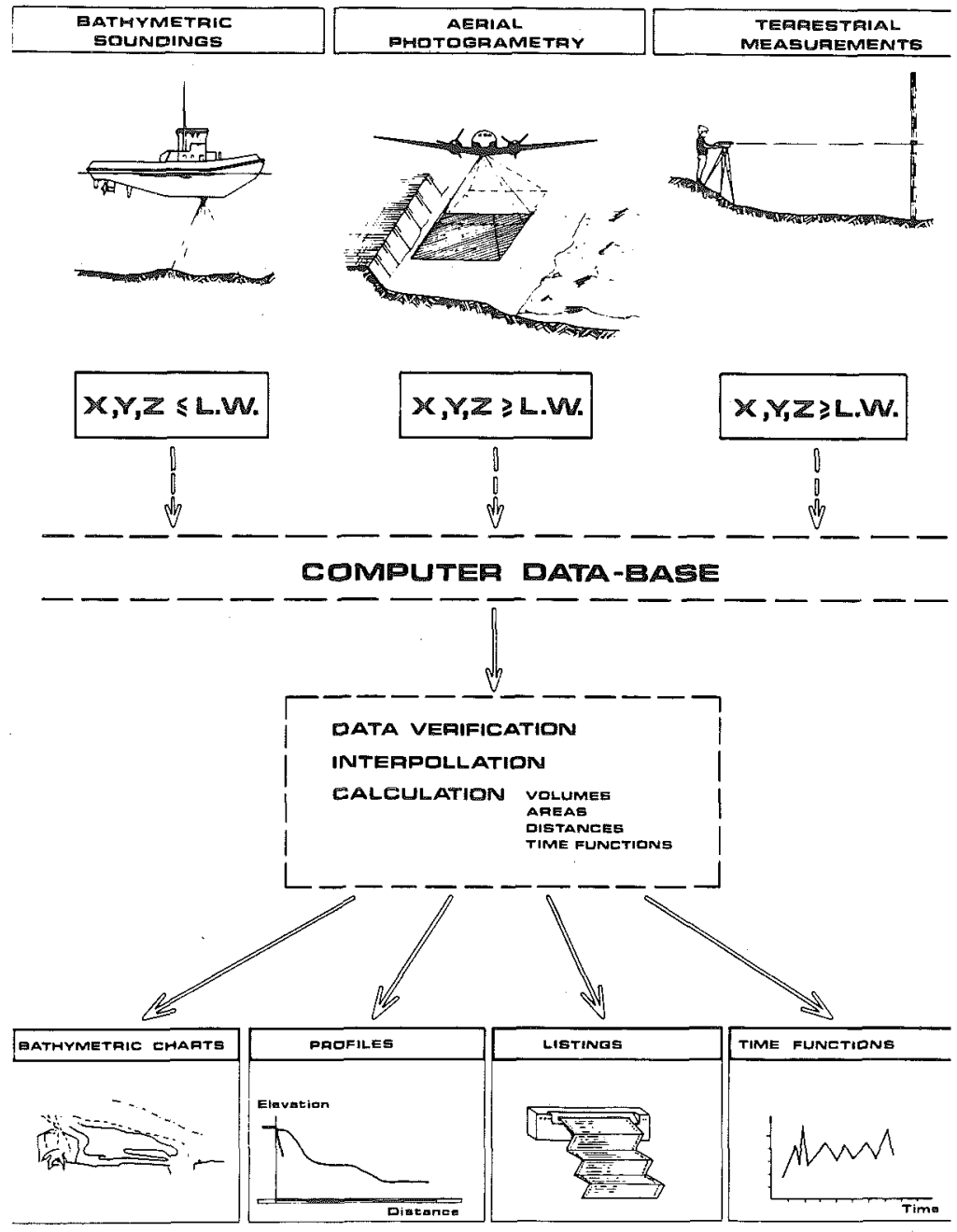

FIG. 3.-Processing of Survey Data 
Based on proven morphological results from the field, one can, where necessary, take practical measures to restore local situations with the help of mathematical transport models. Here, we shall primarily dea with the determination of the morphological evolution at the coast, as described in the upper part of Fig. 2.

\section{Processing Survey Data}

The processing of the survey data into basic end results is shown ir Fig. 3.

Bathymetric soundings and aerial photography take place after the winter and summer periods (twice a year). The bathymetric soundings (after tidal corrections) and the photogrammetric results (after stereo scopic restitution) are brought together into a common computer data. base. From here the data can be verified, interpolated and processed intc workable parameters per groyne-bay. With the aid of these new fielc values, volumes and areas are calculated for each groyne-bay. The po sitions of certain baselines, such as high and low-water can be recal culated.

Terrestrial surveys occur monthly along 11 set-lines of beach profile between the sea dyke and the low-water-line. The terrestrial measure ments of the beach profiles are likewise digitized in the data-base for a comparative analysis. Using the common database one can produce many different types of track-plots and graphical representations, a few of which will now be examined in detail.

\section{Definitions}

The total area under observation (about $20 \mathrm{~km}$ of coastline) was sub. divided into two zones (west and east coast) and then further dividec into sections which were selected for their geographical significance os geomorphological interest.

Each coastal section contains a number of groyne bays (Fig. 4); these are coastal areas lying between two successive groynes. The groyne bay spacings are taken to be the smallest block unit for calculating longshore displacement of material on the basis of the survey data.

The hatched-area defines the position of the low-water line. This is calculated by dividing the area by the mean width of the groyne-bay. In the same way, the positions of the dune foot (DF) high-water line (HW) and nearshore bar (NB) are traced-out.

Besides this longitudinal subdivision of the coast into observation zones, it was also necessary to draw up a vertical description of the beach profile to distinguish areas in three dimensions and so obtain real quantities to observe beach evolution.

Fig. 5 gives a cross-section from the seawall to the seaward limit line at $1,500 \mathrm{~m}$ out from, and parallel to, the coast. The profile is split intc five areas:

The Dune Area.-Lying above the Dune Foot (DF) (Chart Datum + 7.00 $\mathrm{m}$ line).

The Backshore Area - Lying between the DF and the HW-line (CD + $4.50 \mathrm{~m})$.

The Foreshore Area.-Lying between the $\mathrm{HW}(\mathrm{CD}+4.50 \mathrm{~m})$ and the 


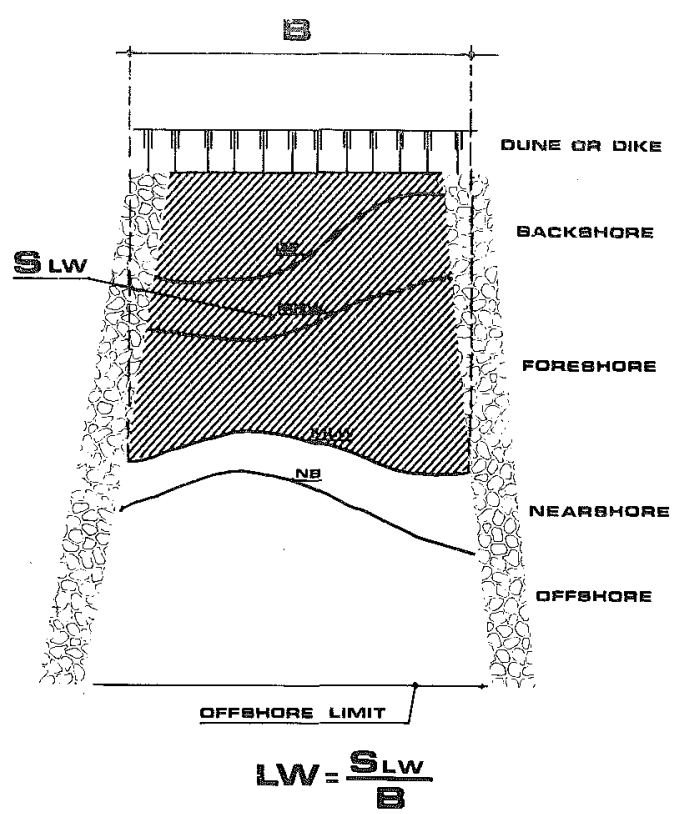

FIG. 4.-Groyne Bay Definitions

$\mathrm{LW}$-line $(\mathrm{CD}+1.5 \mathrm{~m})$ (Backshore + foreshore area $=$ beach area).

The Nearshore Area.-Lying below the LW-line and reaching a depth of about LW $-4 \mathrm{~m}$ (nearshore bar).

The Seabed.-At a depth greater than the nearshore bar $(C D-4.00 \mathrm{~m})$ but not further out to sea than the $1,500 \mathrm{~m}$ cut-off line.

The volumes of dune, beach, nearshore area, and seabed material are expressed in cubic meters per running meter of coastline after dividing by the width of each groyne bay in question. In this way, the volumetric distribution can be compared between adjacent groyne bays. These pa-

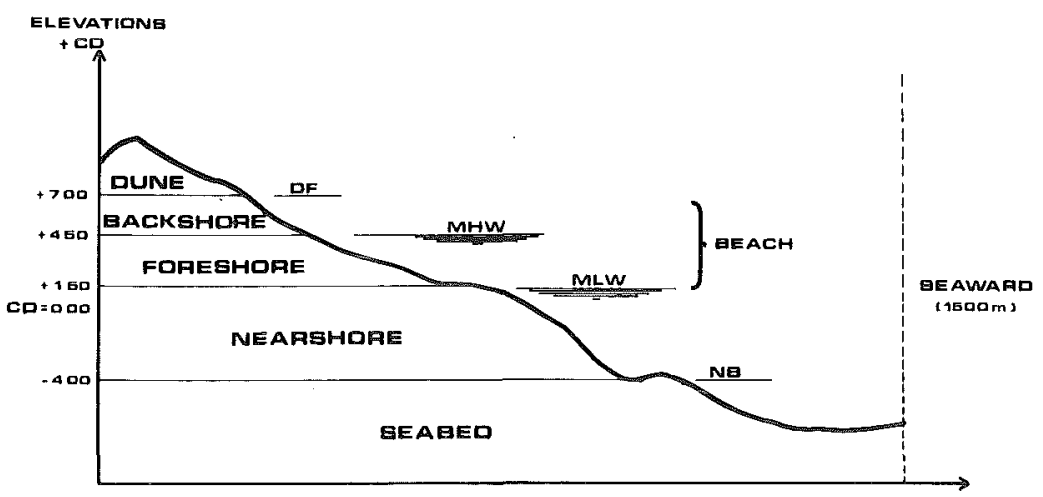

FIG. 5.-Typical Cross Section-Definitions 
rameters are essential to describe the three-dimensional process of coasta morphology.

\section{Analysis of SuRvey Results}

\section{Introduction}

The beach West of Zeebrugge remained stable and only a localizer deposition of sand near the western outer breakwater is observed. Give the importance of the beach nourishment on the east coast, only th results from that coastal zone will now be examined.

\section{Aerial Photogrammetry and Bathymetric Surveys}

We shall first examine the results of calculations based on the data o echo-soundings and aerial-photogrammetric plots carried-out betweer 1979 and 1981. Since the completion of the beach nourishment (Jun 1979), data from five survey campaigns is available with which a prelim inary evaluation can be made of the process of coastal evolution.

Fig. 6 shows results for the dune and beach area; the change in vol ume between the most recent survey period $(T)$ and the reference sit uation of June 1979 is shown. This is given for each groyne-bay alon the east coast and expressed in cubic meters per running meter of coast line.

One can confirm an overall increase in dune growth along the eas coast. This growth is due to the increasing eolian sand-transport, nov that the area of dry sand (beach nourishment) has been enlarged.

In contrast, on the beach (i.e., that part lying between the DF and th
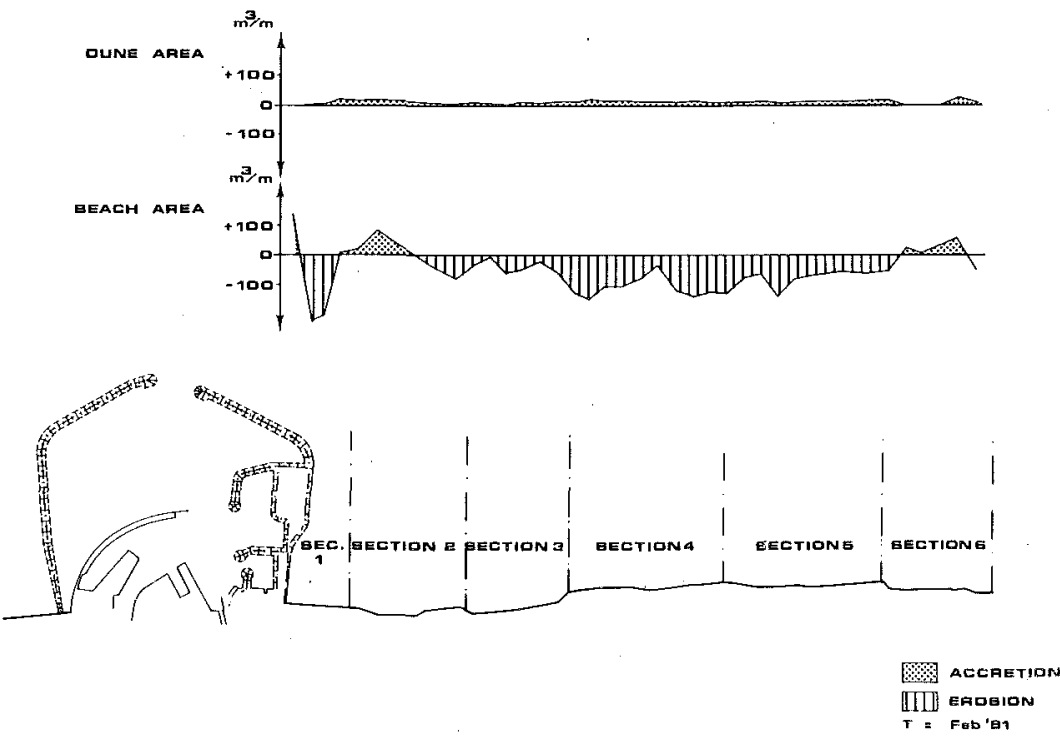

$T=$ Fab'er

FIG. 6.-Dune and Beach Area-Evolution $T / T o$ 
low-water line) erosion predominates over almost the entire length of the east coast. The erosion rates in section 1 are only a localized phenomenon, due to harbor extension works. A normal beach erosion occurred in sections 4 (ca. $230,000 \mathrm{~m}^{3}$ ) and 5 (ca. $180,000 \mathrm{~m}^{3}$ ), decreasing eastwards. The average beach erosion on the east coast is about $50 \mathrm{~m}^{3} / \mathrm{m}$.

This erosion is at its strongest in the foreshore area (lying between the HW and the LW line). This foreshore erosion is shown on the mean profile $(S / B$ ) and is presented for section 4 (Fig. 7); one sees clearly the out-deepening below the HW line between June 1979 and February 1981.

The continual erosion of the foreshore zones in sections 4 and 5 is clearly shown on the graph giving volumes versus time (Fig. 7). The erosion of the foreshore area is due mainly to beach instability after nourishment which results in a state of equilibrium between the nearshore area and the sedimentation of the seabed area.
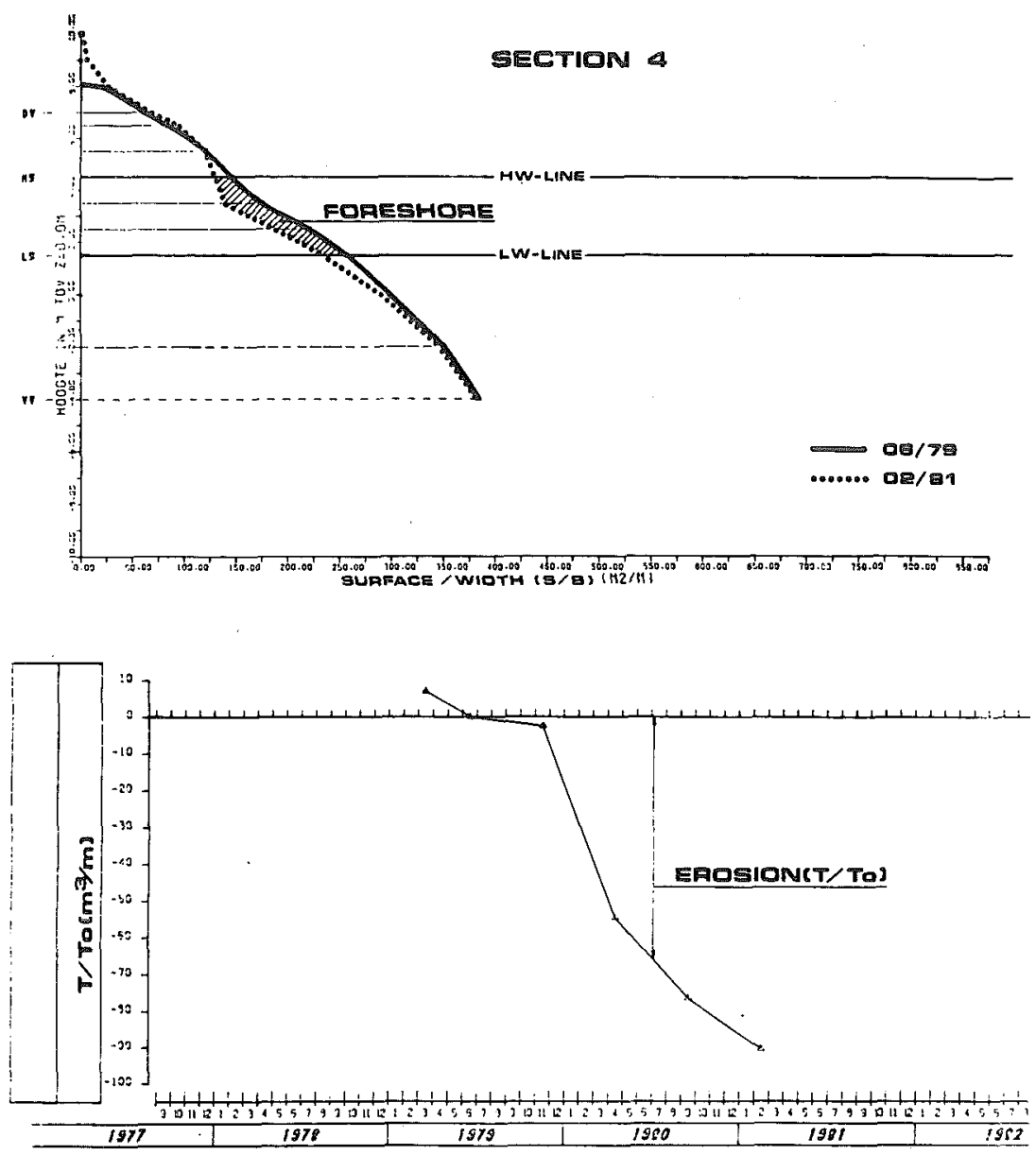

FIG. 7.-Foreshore Erosion (Section 4) 


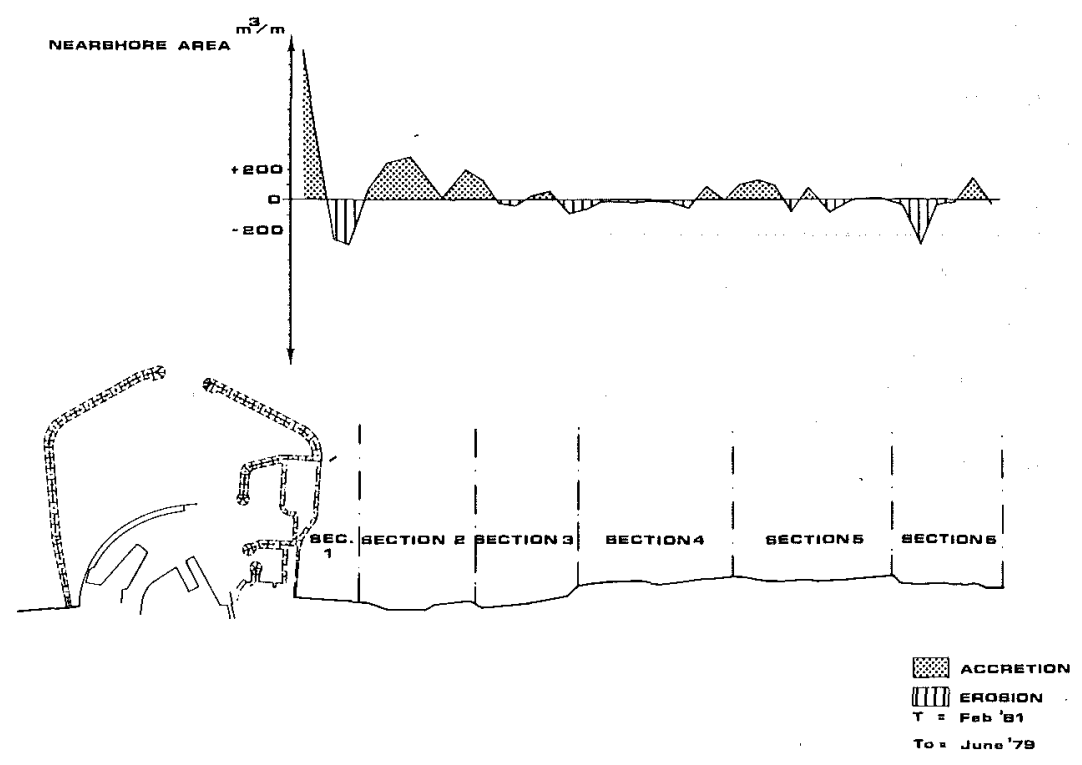

FIG. 8.-Nearshore Area-Evolution $T / T o$

Fig. 8 shows the changes in volume reported for the nearshore area. The changes in this coastal area are irregular, with both accretion and erosion. In the vicinity of section 2, particularly, a major deposition of sand since beach nourishment is observed.

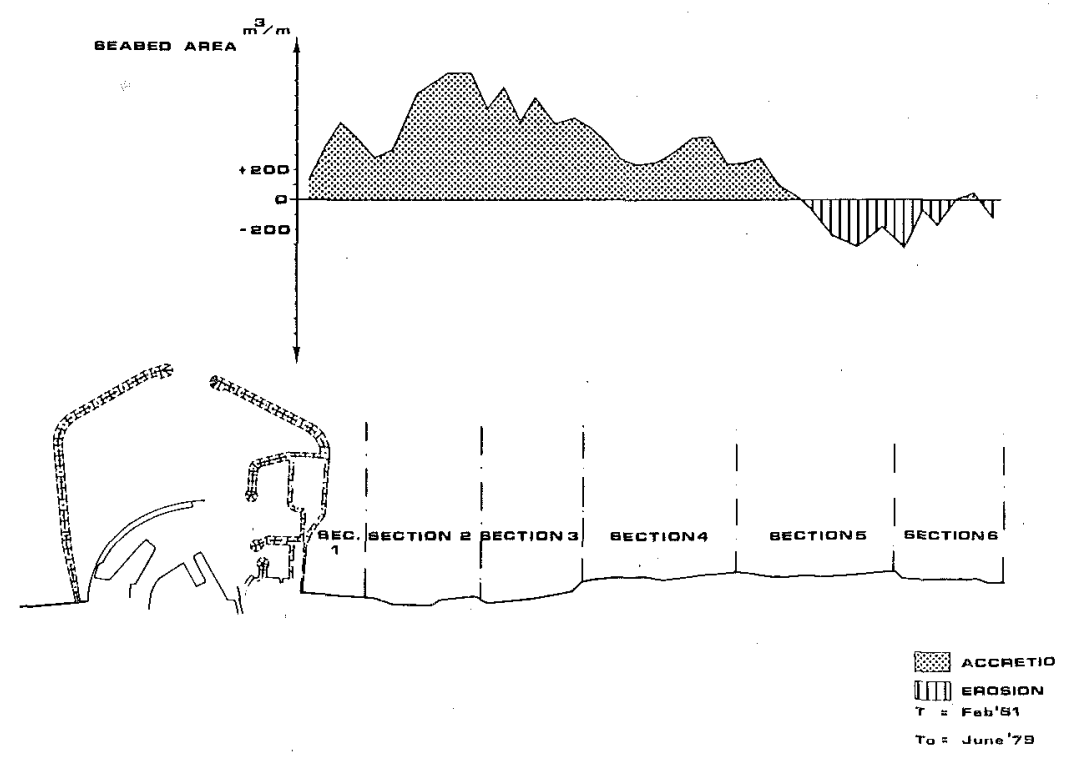

FIG. 9.-Seabed Area-Evolution $T / T o$ 
In Fig. 9 the changes of the seabed are given: from section $1-4$ a significant deposition can be observed. Near section 6 this accretion transforms into an erosion, being particularly apparent during the winter of 1980-1981. The latest bathymetric charts also illustrate the favorable evolution of the seabed over the period June 1979 (after beach nourishment)-Feb. 1981. The gully in front of the beach area has shifted eastward and reduced significantly.

These figures confirm that beach erosion, on the one hand, can lead to dune accretion through increased eolean transport, and that, on the other hand, beach instability can lead to suppletion of the offshore profile. The beach erosion does, therefore, not constitute a new loss to the coastal regime, but is a result of a dynamic equilibrium within the ongoing evolution of the coast.

In summary, two years after beach replenishment, approximately $470,000 \mathrm{~m}^{3}$, or about $6 \%$, of the newly placed sand has been lost from the beaches of the east coast to the dune and offshore areas. The beach erosion is mostly in the foreshore area between HW and LW.

\section{Terrestrial Beach Surveys}

The previously mentioned evolutionary cycles are based on photogrammetric and bathymetric data from survey campaigns which were carried-out until spring ' 81 . One must not forget, however, that the same coastline has also been regularly surveyed along set lines of 11 beach profiles. These monthly editions of data are used to apply an independent control in understanding the beach and dune behavior.

The proven erosion on the east coast in section 4 is visible in profile 104 (Fig. 10): the regression of the foreshore area between June 1979 and February 1981 is particularly evident. Note also the February and August 1982 profiles. Clearly, the erosion has continued.

The long-term tendency is seen even better on the time-function printout (Fig. 11). Time is given by the abcissas. The ordinate shows the dis-

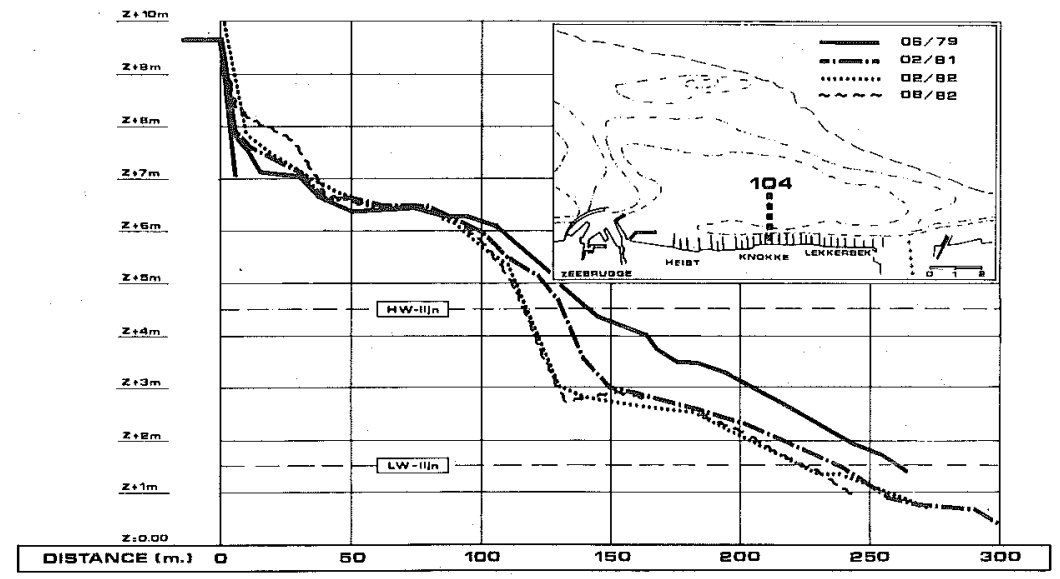

FIG. 10.-Beach Profile 104 (Section 4) 


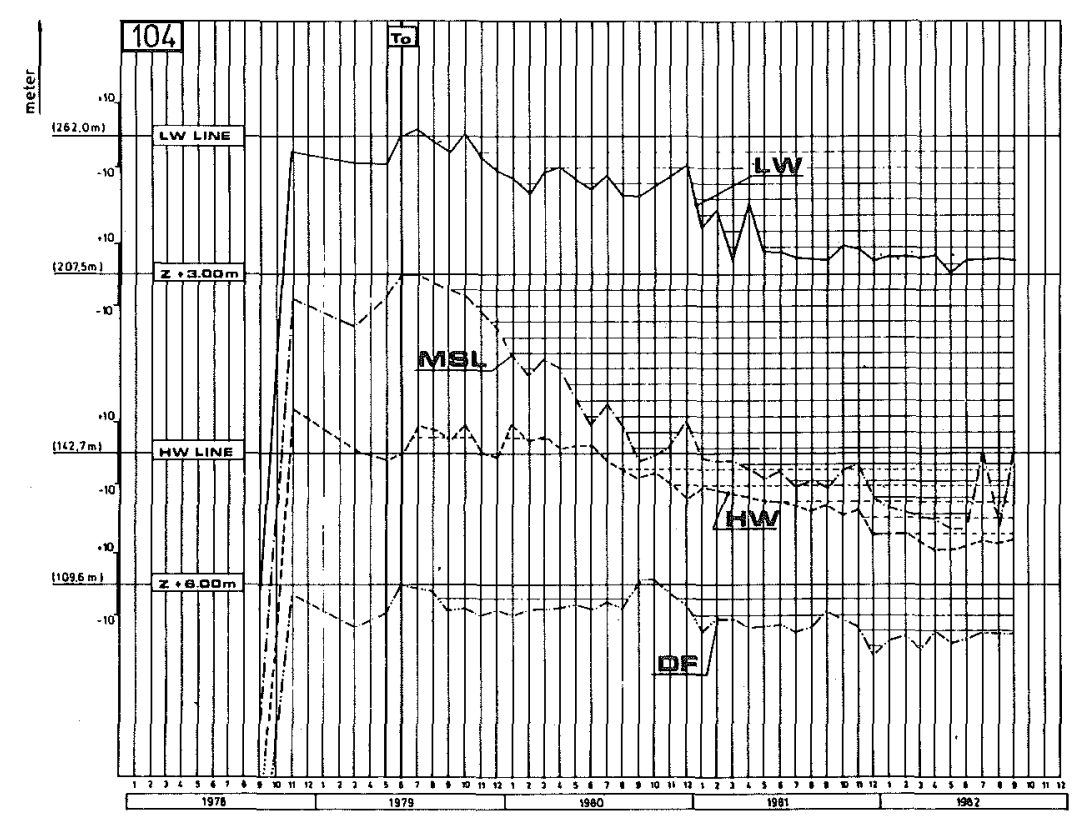

FIG. 11.-Profile 104 (Section 4): Time Function

placement of the different water-marks with respect to the reference situation. The LW, MSL, HW and DF lines all retreat progressively. Since June 1982 the progressive regression has stopped and at present the profile seems to have stabilized.

\section{Future Trends}

On the basis of these results it is clear that the east coast demands constant monitoring. It is especially important to note that in the coastal zones at sections 4 and 5, a permanent beach erosion could undermine the coast or that a dynamic equilibrium could be established between the beach and the seabed area. In addition, the influence of the seaward port extension on the eastern beaches must be constantly monitored.

Also, accuracy with which the sediment transports, elaborated earlier in the paper, can really be calculated must be determined. By selective use of new survey material one can attempt to define the accuracy of the in-situ measurements themselves. Only then can one proceed with reliability to make a serious forecast on how the nourished beaches on the east coast will react as a function of time and the port extension. Moreover, synchronizing the echo-soundings with the photogrammetric output is necessary.

Finally, hydraulic and transport measurements are needed to optimize existing mathematical models. This will allow corrective measures, to be taken by the Belgian Ministry of Public Works, to be foreseen well in advance, and thus made more efficient. 


\section{APFENDIX D PEFEAENCE}

1. Roovers, P., Kerckaert, P., Burgers, A., Noordam, A., De Candt, P., "Beach protection as part of the Harbour Extension at Zeebrugge, Belgium," Papers XXV International Navigation Congress, Volume 5, Section 2. Edinburgh, 1016th May 1981. 